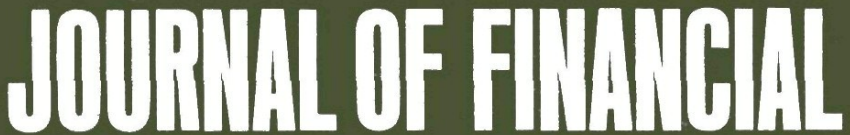

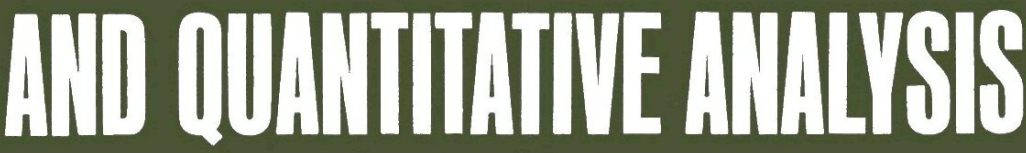

\section{March 1979}

FROM THE EDITOR

R. C. STAPLETON and M. G. SUBRAHMANYAM Marketability of Assets and the Price of Risk

MILES LIVINGSTON

Taxation and Bond Market Equilibrium in a World of Uncertain Future Interest Rates

WILBUR G. LEWELLEN, RONALD C. LEASE, and GARY G. SCHLARBAUM

Investment Performance and Investor Behavior

J. CLAY SINGLETON and JOSEPH R. LAUER

The Implications of Recursiveness in Capital Markets-Theory and Empirical Tests

JOSEPH D. VINSO

A Determination of the Risk of Ruin

JOHN D. MARTIN, DAVID F. SCOTT, JR., and ROBERT F. VANDELL Equivalent Risk Classes: A Multidimensional Examination

GEORGE M. McCABE

The Empirical Relationship Between Investment and Financing: A New Look

ROY L. CRUM, DARWIN D. KLINGMAN, and LEE A. TAVIS Implementation of Large-Scale Financial Planning Models: Solution Efficient Transformations

WILLIAM L. SEAVER and DONALD R. FRASER

Branch Banking and the Availability of Banking Services in Metropolitan Areas 
On the advice of the JFQA Advisory Committee, a moratorium has been declared on paper submissions effective July 1, 1979, through June 30, 1980 . During this period no new papers will be accepted, and all manuscripts submitted for initial review will be returned immediately. This moratorium does not apply to papers submitted prior to July 1, 1979; nor will it affect publication of the Journal.

The purpose of the moratorium is to reduce the lengthy backlog of papers awaiting publication. The Committee's reasoning in support of the moratorium and other steps taken to reduce the backlog are discussed in more detail in FROM THE EDITOR in this issue of the Journal. We recognize the severity of a moratorium, but feel strongly that the JFQA will be of greater service to its readers and its authors when publication delays are minimized. Thank you for your understanding and patience. 


\title{
A JOINT PUBLICATION
}

OF THE

\author{
GRADUATE SCHOOL OF BUSINESS ADMINISTRATION \\ UNIVERSITY OF WASHINGTON \\ AND THE
}

WESTERN FINANCE ASSOCIATION

EDITORIAL STAFF

Charles W. Haley, Managing Editor

Lynn Lewicki, Editorial Associate

University of Washington

\section{ASSOCIATE EDITORS}

Richard H. Bernhard, North Carolina State Gerald O. Bierwag, Oregon

Michael J. Brennan, UBC

Andrew H. Chen, Ohio State

Peter A. Frost, Washington

Robert S. Hamada, Chicago

Frank C. Jen, SUNY, Buffalo

George Kaufman, Oregon

Michael A. Klein, Indiana

Alan Kraus, UBC

Cheng-few Lee, Illinois

John G. McDonald, Stanford

Richard Pettit, Houston
George E. Pinches, Kansas

Barr Rosenberg, Berkeley

Gary G. Schlarbaum, Purdue

Clifford W. Smith, Jr., Rochester

Bruno H. Solnik, CESA, Jouy-en-Josas, France

Bernell K. Stone, Georgia Institute of Technology

James Van Horne, Stanford

David A. Walker, Federal Deposit

Insurance Corporation

Richard R. West, Dartmouth

Robert L. Winkler, Indiana 


\section{WESTERN FINANCE ASSOCIATION}

\section{8-79 Executive Committee}

Guilford C. Babcock, President

Donald E. Farrar, President-Elect

Keith Smith, Vice President

D. Stuart Bancroft, Secretary-Treasurer

David H. Pyle, Past President

Charles W. Haley, Editor

Thomas E. Stitzel

Peter Rose

Seha Tinic

William F. Sharpe
University of Southern California University of Utah

University of California, Los Angeles Pacific Lutheran University

University of California, Berkeley

University of Washington

Boise State University

Texan A\&M University

University of Alberta

Stanford University

INSTITUTIONAL MEMBERS

University of Calgary, Faculty of Business

California State College, Bakersfield

Center for Business/Economic Research

University of California, Berkeley

School of Business Administration

University of California, Los Angeles

Study Center for Finance and

Business Economics
Loyola Marymount University

College of Business Administration University of Southern California Graduate School of Business Administration University of Utah Department of Finance

\section{CORPORATE SPONSORS}

Security Pacific National Bank

Wells Fargo Bank

Transamerica Corporation

Bank of America

Huntsman Chemical \& Oil Corporation

Mattel, Inc.
Los Angeles, California

San Francisco, Californta

San Francisco, California

San Francisco, California

Salt Lake City, Utah

Hawthorne, California

Copyright 1978 by the Graduate School of Business Administration, University of Washington. 
The Journal of Financial and Quantitative Analysis is published by the Graduate School of Business Administration, University of Washington, Seattle, Washington 98195, in conjunction with the Western Finance Association. Regular issues are published in March, June, September, and-December, and a Proceedings Issue is published in November. Second-class postage is paid at Seattle, Washington.

The Proceedings Issue contains selected papers, abstracts of papers, discussants' comments, and the proceedings of the Western Finance Association meetings. From time to time a special issue, devoted to one topic of interest to the membership, is published.

The views and opinions expressed are those of the authors and do not necessarily reflect those of the Graduate School of Business Administration of the University of Washington nor of the Western Finance Association.

For individuals, the annual subscription rate to the JFQA is $\$ 17.50$ (three-year rate, $\$ 47.50$ ); for firms or libraries, the annual rate is $\$ 25.00$ (three-year rate $\$ 70$ ). Annual subscription rates for individuals and libraries outside the United States (except Canada) are $\$ 18.50$ for individuals (three-year rate $\$ 50.50$ ), and $\$ 26.00$ for libraries and firms (three-year rate, \$73). Single copies are $\$ 5.00$. The fiscal year of the Journal of Financial and Quantitative Analysis begins on January 1.

Manuscripts and $\$ 25$ submission fee per manuscript ( $\$ 15$ for W.F.A. members) as well as editorial correspondence, should be sent to the Managing Editor. Correspondence relating to advertising, subscriptions, and billing should be addressed: Subscription Manager, JFQA, University of Washington, DJ-10, Seattle, WA 98195.

Correspondence pertaining to the Western Finance Association should be sent to Mr. D. Stuart Bancroft, Secretary-Treasurer, School of Business Administration, Pacific Lutheran University. Tacoma, WA 98447.

Journal of Financial and Quantitative Analysis - ISSN 0022-1090/USPS 872-260 
July 1979 marks a watershed for the JFQA. After 11 years of close association with the Journal, Charles W. Haley has announced his resignation as Managing Editor to become Rainier Bank Professor of Banking and Finance. Chip has devoted countless hours to the Journal, largely without compensation. He has left his personal stamp on the JFQA, and we all owe him our gratitude for a job well done.

As I assume the editorship, the quality and reputation of the Journal are at all-time highs. Subscriptions and manuscripts submissions have reached new peaks and show every sign of increasing. My intention as editor is to keep the IFQA on the forefront of the profession by continuing to emphasize rigorous, innovative research in finance.

To tighten the bonds between the Journal and its cosponsor, the Western Finance Association, the Executive Committee of the Association at its June meeting appointed a JFQA Advisory Committee. Present committee members are: Professors Guil Babcock, Charles D'Ambrosio, Don Farrar, Alan Kraus, Bill Sharpe, Seha Tinic, and myself.

One price of success for the Journal has been a growing backlog of accepted papers awaiting publication, and a related backlog of submitted manuscripts in the process of review. A paper accepted today would not appear in the Journal for about 18 months. It is my feeling, and that of the Advisory Committee, that these backlogs have grown too long. To reduce the backlogs, several steps have been taken. First, a moratorium has been declared on paper submissions effective July 1, 1979, through June 30, 1980. During this period no new papers will be accepted, and all manuscripts submitted for initial review will be immediately returned. The moratorium will have no effect on papers submitted prior to July 1, 1979, nor will it affect publication of the Journal. The JFQA acceptance rate is presently 18 to 20 percent. The Committee considered and rejected the possibility of dropping the rate temporarily down to the 5 percent range. It was felt that this would simply draw out the task of reducing the backlog, would put an unreasonable burden on reviewers, and would justifiably anger authors of rejected papers.

A second step taken to reduce the backlog will be to increase temporarily the size of each issue. To defer the added costs of increasing the size of each issue and to reduce the University of Washington's growing subsidy to the Journal, the Association has voted to increase dues (which include subscription to the JFQA) from $\$ 15.00$ per year for individuals to $\$ 17.50$. Finally, to help control future backlogs, preference will be given to shorter papers. In general, a manuscript over 20 pages in length, doublespaced, will have to be particularly worthy to merit publication.

I recognize the severity of some of these steps, but feel strongly that the JFQA will be of greater service to its readers and authors, and will ultimately attract better papers, when publication delays are minimized.

Robert C. Higgins

Managing Editor 
JOURNAL OF FINANCIAL AND QUANTITATIVE ANALYSIS

University of Washington, Seattle, Washington

Vol. XIV, No. 1, March 1979

Marketability of Assets and the Price of Risk

R. C. Stapleton and $M$. G. Subrahmanyam

Taxation and Bond Market Equilibrium in a World

of Uncertain Future Interest Rates

Miles Livingston

Investment Performance and Investor Behavior

Wilbur G. Lewellen, Ronald C. Lease, and Gary G. Schlarbaum

Equivalent Risk Classes: A Multidimensional Examination

John D. Martin, David F. Scott, Jr., and Robert $F$. Vandell

The Empirical Relationship Between Investment and Financing: A New Look

George M. McCabe

Implementation of Large-Scale Financial Planning Models: Solution Efficient Transformations

Roy L. Crum, Darwin D. Klingman, and Lee A. Tavis

Branch Banking and the Availability of Banking Services

in Metropolitan Areas

william L. Seaver and Donald R. Fraser 